\title{
Trans-synaptic retrograde degeneration in the visual system of primates
}

\author{
J. M. VAN BUREN \\ From the Branch of Surgical Neurology, National Institute of Neurological \\ Diseases and Blindness, National Institutes of Health, U. S. Public Health Service, \\ Department of Health, Education and Welfare, Bethesda 14, Maryland
}

\begin{abstract}
Although the first observations of trans-synaptic degeneration in the nervous system were made in the nineteenth century, the phenomenon has been something of an infrequent curiosity. From an experimental point of view it is not a particularly attractive field for study due to the time required for the full effects to become evident and may entail many months or even years of waiting. Consequently the majority of the observations have been made in man. Naturally occurring human lesions, even old cerebral infarctions, which are perhaps the most useful for anatomical purposes, practically never approach the discreteness of an experimental ablation since cerebral vascular disease is seldom a localized process. Although this material is of great value, usually the neuropathologist cannot undertake a comprehensive study of the entire brain in serial section so that one is left with the somewhat uncomfortable thought that possibly significant lesions had been missed in the neuropathological sampling.

In the course of another study on the topographical anatomy of the ganglion cell layer of the retina in primates (Van Buren, 1963), long-term chronic lesions were placed in the visual system. This study presents three cases of retrograde trans-synaptic degeneration. In two cases cavitary degeneration appeared in the inner nuclear layer of the retina after section of the axons of the ganglion cells at the optic chiasm. In the last case degeneration of the ganglion cell layer of the retina followed an occipital ablation.
\end{abstract}

\section{METHODS}

In December 1954 an operation to section the optic chiasm was carried out in two adolescent Macaque monkeys ( $\mathrm{M}$ V and $\mathrm{M}$ VI) using pentobarbital anaesthesia. The chiasm was reached by a low left subfrontal approach after sectioning the olfactory tract. It did not seem possible that we could have interfered with the vascular supply of the right eye and orbit in the procedure. In August 1956 the animals were again anaesthetized and were killed by perfusion-fixation of the brain with formalin. The right eye of each animal was removed and fixed in $10 \%$ formalin after injection of a small amount of undiluted formalin into the vitreous. The left eye was stained intravitally with methylene blue and has been used in another study (Van Buren, 1963). After fixation, the optic globes were opened, as much of the vitreous removed as was possible, and the posterior half of the globe trimmed to facilitate orientation for sectioning in the horizontal plane. Both the brain and the right eye of each specimen were embedded in paraffin and serially sectioned. The brain series was stained with? cresyl violet and a myelin method (Heidenhain). The eye sections were stained with cresyl violet, phosphod tungstic acid-haematoxylin, myelin, and modified Bodian methods.

In September 1954 a similar Macaque monkey (M XII was anaesthetized and a right occipital lobectom carried out. In September 1958 the animal was again anaesthetized and killed by perfusion-fixation of the brain. The brain and both eyes were treated as outlined above except that the brain was embedded for serial section in celloidin and cut in a horizontal plane parallel to the optic tracts.

\section{RESULTS}

Under the conditions of the present experiment, retrograde trans-synaptic retinal degeneration was found to follow lesions located in the occipital cortex and in the optic chiasm of the Macaque monkey.

TRANS-SYNAPTIC RETROGRADE DEGENERATION FROM A LESION OF THE OPTIC CHIASM Cases M V and M VI were instances in which the optic chiasm was sectioned 20 months before death. Paired transverse sections of the brain stained with cresyl violet and myelin had been taken at $400 \mu$ intervals and the pathological findings were essentially similar in both animals. There was surprisingly little obvious evidence of degeneration in the optic tracts but the lateral geniculate bodies showed a symmetrical and well-marked degeneration of the first, fourth, and 
sixth layers (numbered from the hilum outward). Some cells, however, remained in the lateral extremities of these laminae in the anterior half of the nucleus. The topography of the retinal ganglion cell distribution was studied by reconstruction and has been presented elsewhere (Van Buren, 1963). M V showed a virtually complete loss of ganglion cells on the medial aspect of the fovea while a ganglion cell layer 1 cell in thickness extended into the inferior mesial retina in M VI. Thus in retrospect it appeared that the surgical section of the chiasm had not been complete, sparing the most inferior posterior crossing fibres. This was of greater degree in M VI than in $\mathrm{M} \mathrm{V}$.
The retinal pathology was essentially similar in both cases (Fig. 1 and Fig. 2). The eyes showed extensive loss of cells in the ganglion cell layer of the medial side of the fovea. Only a few small rounded nuclei remained in this layer and were presumed to be glial in nature. The nerve fibre layer was not evident on the medial margin of the fovea and was only seen quite near the papilla where it thickened abruptly (cf. Fig. 1). No change was evident in the internal plexiform layer. The inner nuclear layer showed cystic degeneration in the retina medial to the fovea. This did not start at the foveal margin but some distance away (M V, 530 $\mu$; VI, 660 $)$ and extended medially for a little over a millimetre
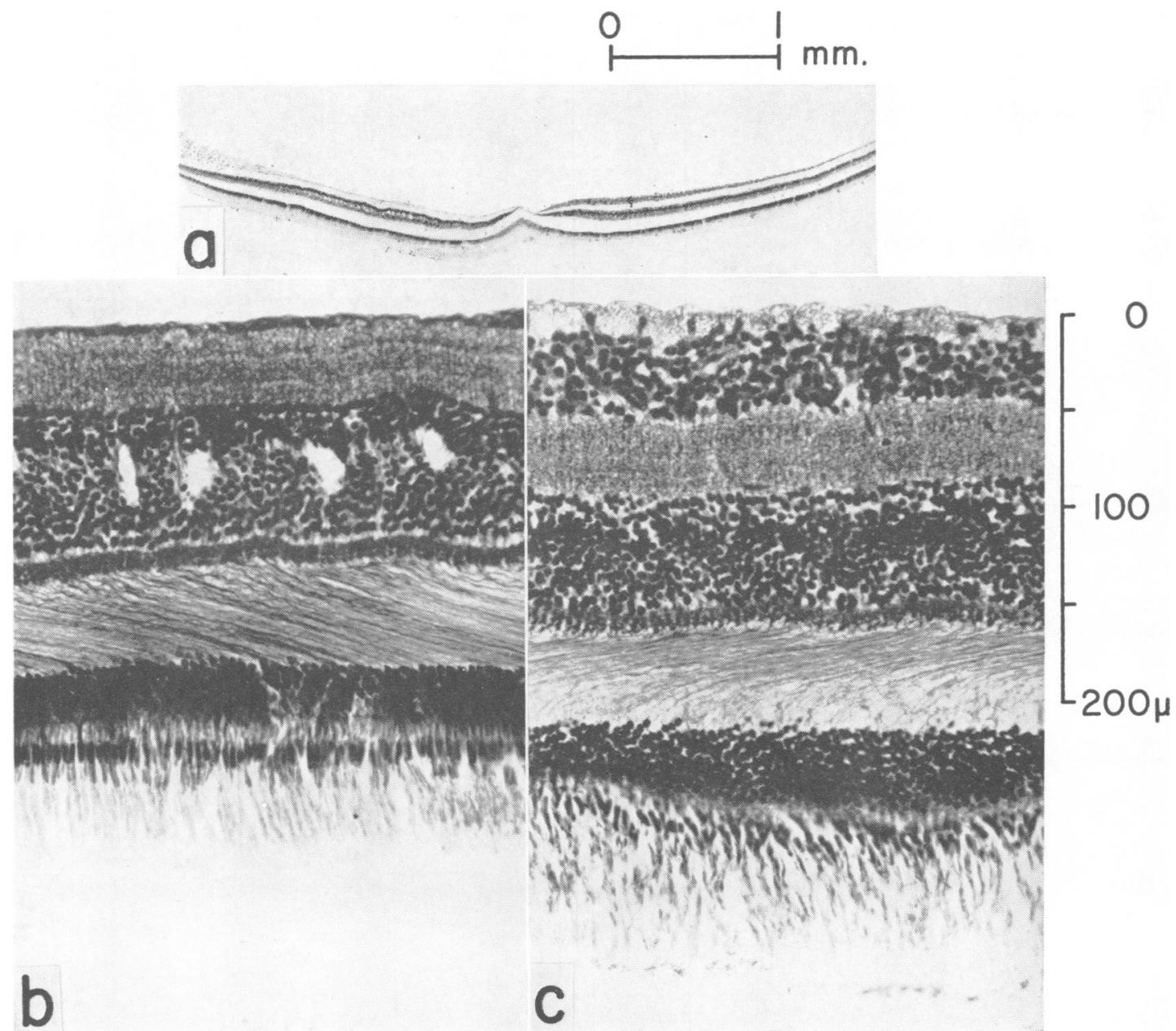

FIG. 1. MV: Horizontal section through the fovea of the right eye 20 months after section of the chiasm. In (a) the margin of the papilla is at the extreme left with loss of ganglion cells and cavitation in the bipolar layer on the medial side of the fovea. In (b) and $(c)$ sections at higher power on the medial and lateral side of the fovea are shown. (a) cresyl violet; (b) and (c) phosphotungstic acid-haematoxylin stains. 
where the cysts became progressively smaller and finally were lost altogether at $1,440 \mu$ from the fovea in M V and $2,260 \mu$ in M Vl. The cystic spaces were irregularly rounded and the larger contained fine strands of tissue and debris. In the phosphotungstic acid stain the Müller fibres were faintly stained but did not appear to be hypertrophied. The outer plexiform, outer nuclear, and bacillary layers and the outer limiting membrane were intact.

RETROGRADE TRANS-SYNAPTIC DEGENERATION FROM AN OCCIPITAL LESION Gross examination of the brain of M XII 48 months after a right occipital lobectomy showed that the occipital lobe had been removed anteriorly to the level of the splenium of the corpus callosum. The line of resection extended laterally and slightly posteriorly. Serial sections showed a small residual area of primary visual cortex (area OC of von Economo, 1927) which was reconstructed in relation to the gyral pattern on the lateral photograph (Fig. 3). The right lateral geniculate body showed gross atrophy while the left appeared quite normal (Fig. 4). On the right the laminar pattern was vaguely retained by debris apparently consisting largely of nuclear fragments which stained faintly with cresyl violet. Fifteen sections passed through the right lateral geniculate body and on these a count of intact neurons was made. The counts on individual sections were plotted as a graph against the serial section numbers below which were given as a complete series. The actual counts on the graph were joined by a freehand line and the area under the curve determined by the paper weight method. In this fashion the total

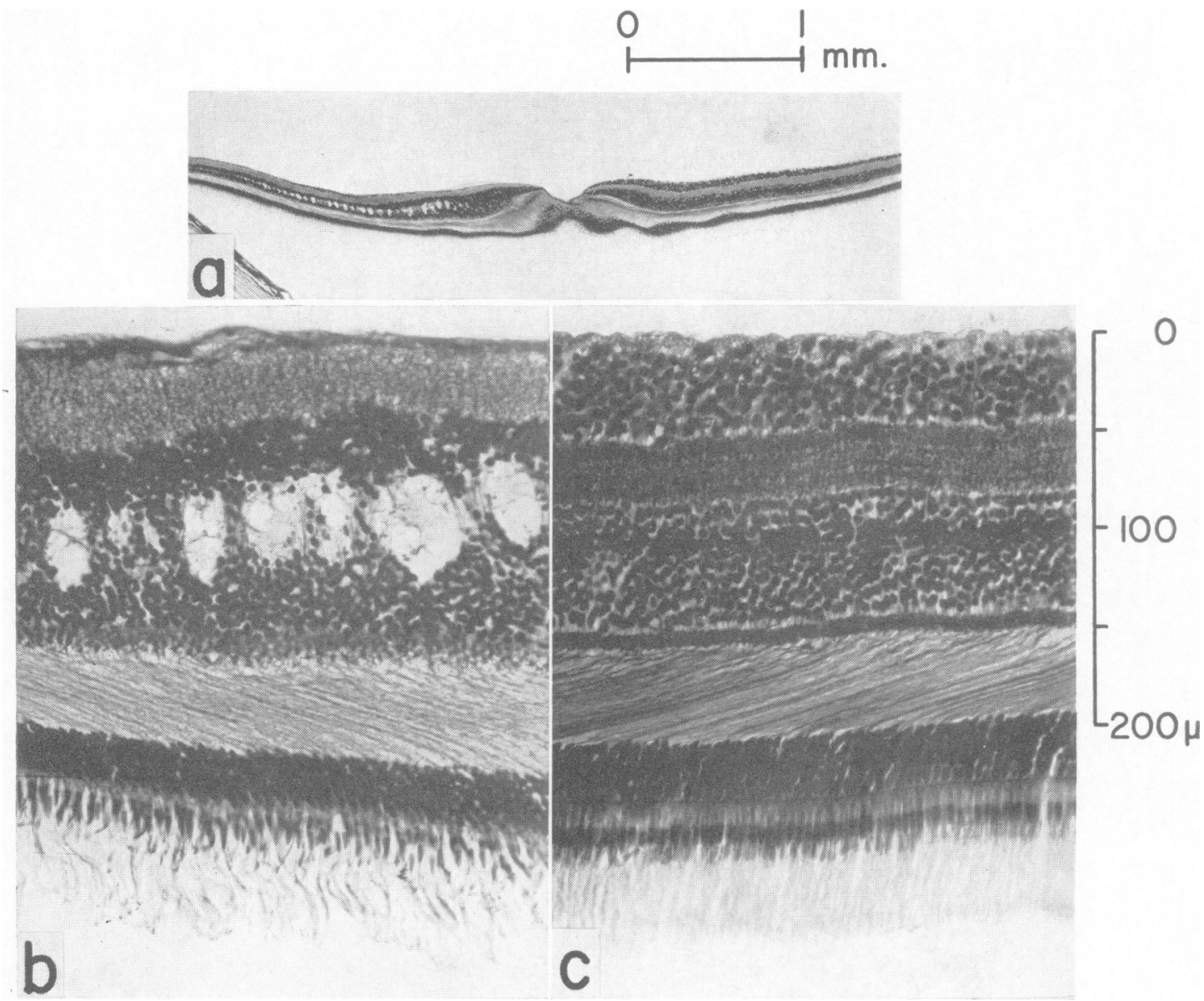

FIG. 2. MVI: Horizontal section through the fovea of the right eye 20 months after section of the chiasm; (a) shows loss of ganglion cells and cavitation in the bipolar layer on the medial side of the fovea; (b) and (c) show the same changes at higher power. (a) Stained with cresyl violet; (b) and (c) with phosphotungstic acid-haematoxylin. 


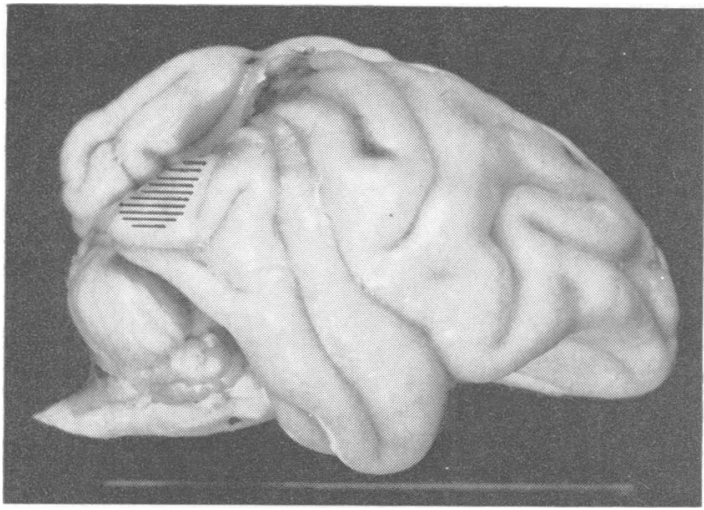

FIG. 3. The lateral aspect of the brain of M XII 48 months after a right occipital lobectomy. The area of retained primary visual cortex has been hatched.

FIG. 4. M XII: Horizontal section of the brain parallel to the optic tracts. Observe the atrophy of the right lateral geniculate nucleus in comparison with the left 48 months after right occipital lobectomy. Celloidin, cresyl violet stain.

FIG. 3.

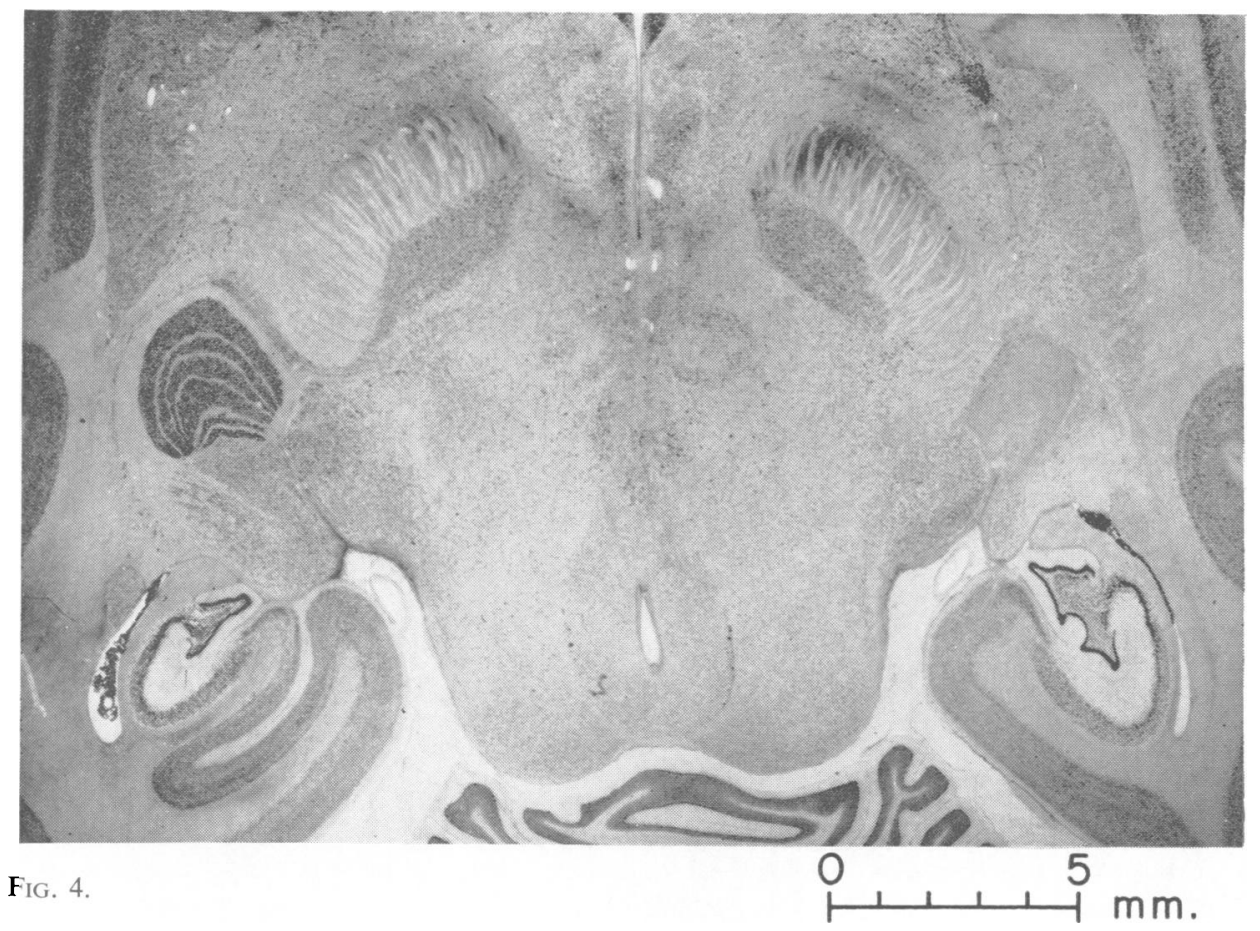

residual count was estimated to be 1,939 cells $(26 \%$ of these cells were actually counted).

The residual cells showed two distinct distribution patterns. Five hundred and one cells lay singly at wide intervals throughout the upper half of the nucleus and usually in the lateral half of the nucleus. One thousand four hundred and thirty-eight cells lay as a single dense clump in the most posterior, inferior, and lateral extremity of the lateral geniculate body. (This was below the level of section in Figure 4.) This fragment showed the pattern and dense

staining characteristics of the neurons of the lateral geniculate body on the left side.

The optic tract on the right appeared densely myelinated and failed to show any fascicular atrophy. Since the brain had been cut in a horizontal plane parallel to the optic tracts, the cross-sectional area of the optic tracts was determined by reconstruction. The width of the tract was measured along a line perpendicular to its longitudinal axis at the midpoint of its course along the lateral border of the cerebral peduncle. The left optic tract was present on 11 

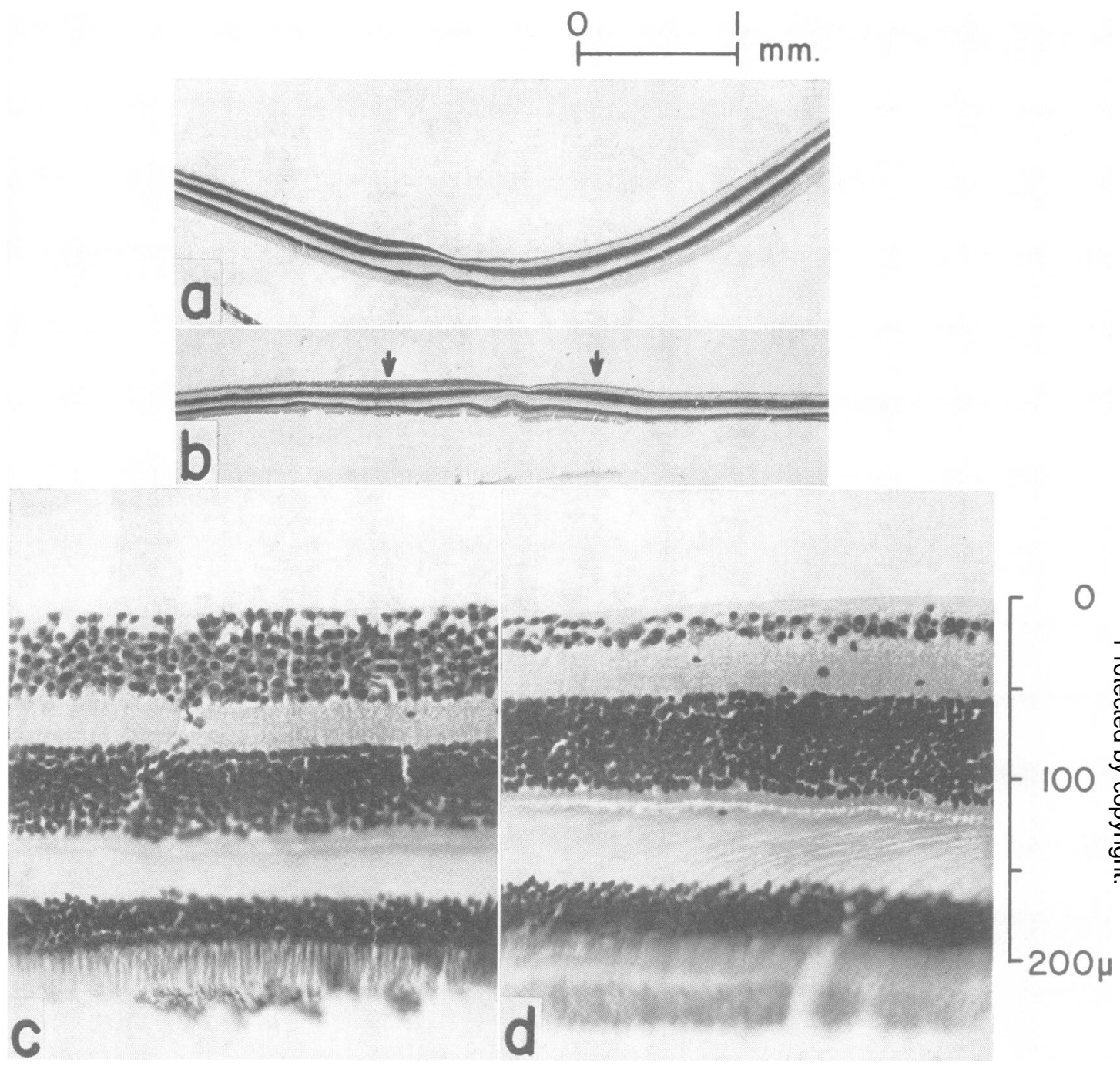

FIG. 5. M XII: Note the loss of ganglion cells on the right side of the retina in both the right (a) and left (b) eyes 48 months after right occipital lobectomy. Higher power views $(c)$ and $(d)$ of the left retina show the retina, respectively, on the left and right sides of the fovea at the levels indicated by arrows in $(b)$. Cresyl violet stain.

sections and the right on eight. The actual measurements were made from an image projected at a magnification of 40 (Van Buren, 1960). After reconstruction, the area of the optic tracts was determined by weighing the paper cut-outs. The left optic tract had an area of $5.56 \mathrm{~mm}^{2}$ and the right $2.45 \mathrm{~mm} .^{2}$, or, better (since the shrinkage of the specimen was unknown but presumably symmetrical) the right tract had $44 \%$ of the cross section area of the left.

Examination of myelin, phosphotungstic acid- haematoxylin, and silver preparations of cross sections of the optic nerves failed to show any discrete areas of degeneration.

Both retinae showed a well-defined loss of ganglion cells on the right side of the fovea (Fig. 5). This appeared as a thinning of the layer so that it did not $D$ exceed 2 cells in thickness on the right of the fovea whereas it was at least 6 cells thick and considered $N$ normal on the left. The change was symmetrical in the two eyes although it should be noted that the right retina was cut somewhat obliquely so that the 
layers appeared slightly thicker than in the left retina. No abnormality was seen in the deeper retinal layers.

The topographical reconstruction of the residual ganglion cells (Van Buren, 1963) showed that although gross thinning of the ganglion cells appeared in the right retina, layers 1 and 2 cells thick extended laterally along the horizontal meridian instead of falling off immediately at the foveal margin as in cases $\mathrm{M}$ V and M VI above. This preservation is considered to be related to the retention of the lateral extremity of the primary visual cortex.

\section{DISCUSSION}

The presence of retrograde cell change after axonal damage was perhaps first evaluated in the visual system, since Schultze (1872) credited Lehmann with the discovery that the ganglion cells of the retina degenerate after severance of the optic nerve and hence that the optic fibres are the axis cylinders of the retinal ganglion cells. Ganser (1882) confirmed the degeneration of retinal ganglion cells nine months after a lesion of the optic tract in a newborn kitten. This observation has been repeated by modern investigators (James, 1933; Leinfelder, 1938; Polyak, 1941; Mantz and Klein, 1951; Eayrs, 1952) with the production of little additional information apart from some discussion as to the degree of resistance of the large ganglion cells. In cats Leinfelder (1938) came to the conclusion that large ganglion cells were less affected by section of the optic nerve, while in rats Eayrs (1952) came to the opposite conclusion. Recently a single human case was reported by Gartner (1951).

Although Greenfield concluded (1958) that secondary cell changes (chromatolysis) do not occur in retinal ganglion cells after axonal injury chromatolytic changes have been reported shortly after section of the optic nerve in animals (BirchHirschfeld, 1900; James, 1933) and abortive attempts are made at regeneration ( $c f$. Tello and Leoz; Cajal, 1928). The duration of these regenerative efforts and the time required after section of the axon before the ganglion cells are exhausted and begin to degenerate is apparently unknown.

More difficult to explain from a theoretical standpoint is the presence of 'trans-synaptic degeneration' (Foix, Chavany, and Hillemand, 1926) in which the next cell in the chain of neuronal conduction to the injured one also degenerates. Greenfield (1958) observed that 'trans-synaptic degeneration seems to occur most commonly after lesions of tracts which form the chief or the only afferent link to the neurons in question'.

Perhaps the best known example of anterograde trans-synaptic degeneration, i.e., degeneration proceeding to neurons which lose their afferent supply of neuronal impulses, is that of the lateral geniculate body following section of an optic nerve or optic tract (Minkowski, 1920a, 1920b; Brouwer and Zeeman, 1926; Clark, 1932; Cook, Walker, and Barr, 1951; Goldby, 1957; Matthews, Cowan, and Powell, 1960). Destruction of the eyes or optic nerves early in life may even produce thinning of the line of Gennari in the calcarine cortex after a sufficient period (Bolton, 1900; Cajal, 1911). Other examples include degeneration in the inferior olives after lesions of the central descending afferent pathways (Torvik, 1956; Greenfield, 1958), in the mammillary bodies after lesions of the cingulate cortex (Cowan and Powell, 1954), and in the central trigemino-thalamic pathways after alcohol injection of the Gasserian ganglion in man (Penman and Smith, 1950). Recently it has been demonstrated in the olfactory and cochlear systems (Matthews and Powell, 1962; Powell and Erulkar, 1962).

In addition to anterograde degeneration, degeneration may progress in the opposite direction, up stream as it were, from the injured receiving neuron to the nerve cell supplying it with impulses.

Reports of retrograde trans-synaptic degeneration seem less frequent but it nevertheless is well documented. Campbell (1905) reported the finding of degenerative changes in the Betz cells of the precentral area subserving an amputated limb. In his series the earliest case was examined two years following amputation and degenerative cortical changes were present. To Greenfield (1958) retrograde trans-synaptic degeneration seemed the most reasonable explanation for the degeneration of the inferior olives after destruction of the Purkinje cells by heat stroke. He felt it likely that the same mechanism was responsible for degeneration of these nuclei in the familial type of cerebellar cortical degeneration (Holmes 1907) as well as in similar cases of isolated character (Marie, Foix, and Alajouanin, 1922).

Degeneration in the optic nerves and tracts from occipital lesions was reported by a considerable number of older investigators. Moeli (1891) found that lesions of the occipital lobes (porencephaly, hydrocephalus) dating from foetal life caused degeneration passing into the optic tract and optic nerves. Déjèrine (1892) made passing mention of degeneration of the optic nerves from cortical lesions and apparently recognized both anterograde and retrograde trans-synaptic degeneration in the visual system in his later monograph (1901). Recent confirmation of these findings was supplied by Niessl von Mayendorf (1934). Pallor of the optic discs (optic atrophy) following longstanding occipital 
injury with visual field changes has been reported by several workers from clinical observations (Euzière, Viallefont, and Vidal, 1933; Fledelius, 1934; Walsh, 1947; Haddock and Berlin, 1950).

Although before the present observations retrograde trans-synaptic degeneration of the bipolar layer apparently has not been noted, some three instances of retinal changes following occipital ablation were reported. In 1882 Ganser found degeneration in the nerve fibre layer of the retina of both eyes on the same side as a large cerebral ablation. The experiments were done in two newborn kittens which were killed, respectively, six and nine months after the ablation. He was unable to be certain of any change in the appearance or distribution of the ganglion cells. Monakow (1889) after ablation of the occipital lobes in dogs and cats reported not only degeneration of the lateral geniculate bodies but, when the operation was carried out in newborn animals, there was shrinking of the optic tract on the side of the lesion and atrophy of the retinal cell elements. More recently Klüver (1937) made passing mention that four years after an occipital lobectomy in an adult rhesus monkey, Dr. Polyak had found 'a reduced affinity for the stains employed' in the corresponding retinal halves. No further details were furnished regarding this interesting observation.

Although anterograde trans-synaptic atrophy has been characterized, perhaps too briefly, as an 'atrophy of disuse', there seems unequivocal evidence that activity is essential to the normal neurone. In the neonatal period the retina apparently has a particular need for light stimulation in order that further maturation may occur. In this regard the late myelination of the optic and olfactory nerves in comparison with the other cranial nerves (Langworthy, 1930) may be mentioned. Murr (1929) was able to demonstrate in newborn kittens that light increased the length of the visual receptors. Furthermore, Hellström and Zetterström (1956) and Schimke (1959) observed a small but significant decrease in the development of retinal enzymes of kittens and rabbits reared in total darkness from birth. This would appear to be related to Zetterström's (1956) observation that the time of the appearance of $\beta$ waves in the electroretinograms of newborn kittens could be delayed by rearing them in total darkness. In the clinic it has been well recognized for years that failure of the image to reach the retina of a young child because of opacity of the media or persistent failure of the image to fall upon the fovea, as in some heterotropias, will result in impairment of visual acuity which shows little tendency to recover if the original abnormality is later corrected. The observations of Chow, Riesen, and Newell (1957) are of particular interest in this regard, since they found severe histological degeneration of the ganglion cell layer of the retina in two chimpanzees subjected to long periods of darkness. One was reared in darkness from 8 to 24 months of age. The first animal showed failure of histological $\stackrel{\infty}{2}$ retinal maturation while the second indicated that lack of stimulation if sufficiently prolonged may lead to loss of ganglion cells. Why a similar atrophy did . not appear to affect the photoreceptor and bipolar $\vec{F}$ elements is a curious feature since the specific stimulus for the former (light) had been excluded. Contradictory evidence had been reported earlier by Goodman (1932) who found no evidence of impairment in retinal maturation in rabbits reared in darkness.

In the case of retrograde trans-synaptic degeneration, the degenerating cells are upstream from the neuron which was actually destroyed and would seem, at first glance, to be subject to all the conditions and impulses which normally sustain and stimulate them. On further consideration, however, there seems good evidence that a retinal feedback system exists and may have greater importance than is generally supposed at present. The growth of $\mathrm{N}$ centrifugal, i.e., brain to retina, fibres in the optio nerve in embryonic development was observed b\% His (1868) and reaffirmed by Köllicker (18825 Cajal (1911) reported the presence of centrifuga fibres in the retina and this observation was accepted by Polyak (1941). Recently the development. of centrifugally directed growth cones in the severeg human optic nerve has been illustrated by Wolter (1956). Physiological support was suggested by Dodt (1956) who found that stimulation of the optic tract in rabbits elicited small retinal spikes of late appearance which were unlike antidromic spikes and which he interpreted as impulses conveyed along centrifugal fibres to the retina.

Evidence of the central regulation of retinal activity is to be found in Granit's work (1955a, 1955b). During tetanizing stimuli of the mesencephalic reticular substance in the cat, the frequency of discharge of single retinal ganglion cells to a test light stimulus was decreased. For a short period after the termination of the central stimulus there was increased frequency of firing of the cell to the same light stimulus. Occasionally a largely inhibitory response was noted. Finally, a similar response was noted in the case of spontaneous ganglion cell dis- 은 charge. Granit (1955a) pointed out that post- $\supset$ excitatory potentiation in the discharge rate of the ganglion cell could be obtained by tetanizing stimuli applied directly to its axon, but in this instance, antidromic driving of the cell discharge could be observed during the tetanus. In the case of reticular $\mathrm{G}$ 
stimuli a similar driving of the frequency of discharge of the ganglion cell did not appear. Whether the reticular inhibitory impulses to the retina are subject to modification from the occipital cortex has yet to be investigated.

Although these considerations hardly offer an explanation for retrograde trans-synaptic atrophy of retinal neurons after damage to their central connexions, they do, however, remind us that ganglion cell activity may be modified by factors apart from incident illumination. One may speculate whether cell damage may not eventually result more from unregulated and possibly excessive neuronal activity, due to the absence of central and peripheral inhibitory influences, than from lack of the physical modality which serves as the specific physiological stimulus for the retinal cell.

\section{SUMMARY}

Retrograde trans-synaptic degeneration has been noted at two levels in the visual system of the Macaque monkey. In two animals examined 20 months after a surgical lesion of the optic chiasm there was complete loss of ganglion cells in the medial retina and cystic degeneration in the inner nuclear layer. In a single animal studied 48 months after an occipital ablation there was severe loss of ganglion cells in the retinal half corresponding to the lesion.

The previous literature regarding trans-synaptic degeneration has been reviewed and discussed.

\section{BIBLIOGRAPHY}

Birch-Hirschfeld, A. (1900). Albrecht v. Graef's Arch. Ophthal., 50 166.

Bolton, J. S. (1900). Phil. Trans. roy. soc., 193, 165.

Brouwer, B., and Zeeman, W. P. C. (1926). Brain, 49, 1.

Cajal, S. Ramon y (1911). Histologie du système nerveux de l'homme et des vertébrés, vol. 2, Maloine, Paris.

(1928). Degeneration and Regeneration of the Nervous System, vol. 1 and 2, reprinted 1959, trans. R. M. May. Oxford University Press, London. Hafner, New York.

Campbell, A. W. (1905). Histological Studies on the Localisation of Cerebral Function. University Press, Cambridge.

Chow, K. L., Riesen, A. H., and Newell, F. W. (1957). J. comp. Neurol., 107, 27.

Clark, W. E. Le Gros (1932). Brit. J. Ophthal., 16, 264.

Cook, W. H., Walker, J. H., and Barr, M. L. (1951). J. comp. Neurol., 94, 267.

Cowan, W. M., and Powell, T. P. S. (1954). Proc. roy. Soc., B, 143, 114.
Déjèrine, J. (1892). C.R. Soc. Biol. (Paris), 44, 61.

(1901). Anatomie des centres nerveux, vol. 2. J. Rueff, Paris.

Dodt, E. (1956). J. Neurophysiol., 19, 301.

Eayrs, J. T. (1952). Brit. J. Ophthal., 36, 453.

Economo, C. von (1927). L'architecture cellulaire normale de l'écorce cérébrale. Masson, Paris.

Euzière, J., Viallefont, H., and Vidal, J. (1933). Arch. Soc. Sci. méd. biol. Montpellier, 14, 212.

Fledelius, M. (1934). Arch. Ophthal. (Paris), 51, 561.

Foix, C., Chavany, J. A., and Hillemand, P. (1926). Rev. Neurol., 33 (1), 942 .

Ganser, S. (1882). Arch. Psychiat. Nervenkr., 13, 341.

Gartner, S. (1951). Amer. J. Ophthal., 34, 593.

Goldby, F. (1957). J. Neurol. Neurosurg. Psychiat., 20, 202.

Goodman, L. (1932). Amer. J. Physiol., 100, 46.

Granit, R. (1955a). Receptors and Sensory Perception. Yale University Press, New Haven.

- (1955b). J. Neurophysiol., 18, 388.

Greenfield, J. G. (1958). General pathology of the nerve cell and neuroglia. In Neuropathology, by J. G. Greenfield, W. H. McMenemey, W. Blackwood, A. Meyer, and R. M. Norman, p. 1. Arnold, London.

Haddock, J. N., and Berlin, L. (1950). Arch. Neurol. Psychiat. (Chicago), 64, 66.

Hellström, B., and Zetterström, B. (1956). Exp. Cell Res., 10, 248.

His, W. (1868). Untersuchungen über die erste Anlage des Wirbelthierleibes. Die erste Entwickelung des Hühnchens im Ei. Vogel, Leipzig.

Holmes, G. (1907). Brain, 30, 466

James, G. R. (1933). Arch. Ophthal. (Chic.), 9, 338.

Klüver, H. (1937). J. Psychol., 4, 383.

Kölliker, A. V. (1882). Embryologie, ou, Traité complet du développement de l'homme et des animaux supérieurs, translated by A. Schneider. Reinwald, Paris.

Langworthy, O. R. (1930). Contr. Embryol. Carneg. Instn, 21, 39 [No. 120].

Leinfelder, P. J. (1938). Trans. Amer. ophthal. Soc., 36, 307.

Mantz, J., and Klein, M. (1951). C. R. Soc. Biol. (Paris), 145, 922.

Marie, P., Foix, C., and Alajouanin, T. (1922). Rev. Neurol., 29, 849, 1082.

Matthews, M. R., Cowan, W. M., and Powell, T. P. S. (1960). J. Anat. (Lond.), 94, 145.

, and Powell, T. P. S. (1962). Ibid., 96, 89.

Minkowski, M. (1920a). Schweiz. Arch. Neurol. Psychiat., 6, 201.

- (1920b). Ibid., 7, 268.

Moeli, C. (1891). Arch. Psychiat. Nervenkr., 22, 73.

Monakow, C. von (1889). Ibid., 20, 714.

Murr, E. (1929). Biol. Zbl., 49, 156.

Niessl von Mayendorf (1934). Rev. Neurol., 1, 1024.

Penman, J., and Smith, M. C. (1950). J. Neurol. Neurosurg. Psychiat., 13, 36.

Polyak, S. L. (1941). The Retina. University of Chicago Press, Chicago.

Powell, T. P. S., and Erulkar, S. D. (1962). J. Anat. (Lond.), 96, 249

Schimke, R. T. (1959). J. biol. Chem., 234, 700.

Schultze, M. (1872). In Handbuch der Lehre von den Geweben des Menschen und der Thiere, edited by S. Stricker, vol. 2, ch. 36, pp. 977-1034. Engelmann, Leipzig.

Torvik, A. (1956). J. Neuropath. exp. Neurol., 15, 119.

Van Buren, J. M. (1960). Anat. Rec., 136, 363.

, (1963). The retinal ganglion cell layer-A physiologicalanatomical correlation in man and primates of the normal topographical anatomy of the retinal ganglion cell layer and its alterations with lesions of the visual pathways. C. C. Thomas. Springfield, Illinois.

Walsh, F. B. (1947). Clinical Neuro-ophthalmology. Williams and Wilkins, Baltimore.

Wolter, J. R. (1956). Albrecht v. Graefes Arch. Ophthal., 158, 235.

Zetterström, B. (1956). Acta physiol. scand., 35, 272. 